\title{
Cryopreserved peripheral blood cells functioning as autografts in patients with chronic granulocytic leukaemia in transformation
}

\author{
J M GOLDMAN, D CATOVSKY, JILL HOWS, A S D SPIERS, D A G GALTON
}

British Medical fournal, 1979, 1, 1310-1313

\section{Summary and conclusions}

Six patients with chronic granulocytic leukaemia (CGL) in transformation were treated with cytotoxic drugs or cytotoxic drugs plus total body irradiation, followed by infusion of reconstituted autologous peripheral blood cells that had been collected from them at diagnosis and stored in liquid nitrogen for up to 58 months. In four cases the blood and bone-marrow appearances were rapidly restored to those of typical chronic-phase disease. In three of these patients transformation recurred at $\mathbf{7 4}$, 32 , and 26 weeks respectively. One patient was still in second chronic phase at eight weeks. One of the patients who entered a second transformation was restored to a third chronic phase by further treatment with cytotoxic drugs and a second autograft.

Cryopreserved autologous blood cells may thus restore some patients with CGL in transformation to chronic-phase disease and so may help to prolong life.

\section{Introduction}

In 1972 we began to collect and store in liquid nitrogen haemopoietic stem cells from the bone marrow of newly diagnosed patients, intending to reconstitute and transfuse them when the patients subsequently entered transformation and had been treated with cytotoxic drugs to render the bone marrow hypoplastic. ${ }^{12}$ We hoped by this means to repopulate the bone marrow with chronic-phase stem cells, which, though positive for the Philadelphia chromosome $\left(\mathrm{Ph}^{1}\right)$, would be haemopoietically competent. In allogeneic conditions peripheral blood cells from donors with chronic granulocytic leukaemia (CGL) can engraft a patient's bone marrow, albeit transiently. ${ }^{3}$ When, therefore, it became clear that blood leucocytes from patients with CGL included more granulocyte/macrophage-committed precursor cells (colony-forming units in agar culture; CFUc) than comparable numbers of marrow cells ${ }^{4}$ we began to store mainly peripheral blood buffy-coat cells, collected with a continuous-flow blood-cell separator, in preference to bonemarrow cells. ${ }^{2}$ Here we report the preliminary results obtained when we used reconstituted buffy-coat cells as autografts in the management of six patients with CGL in transformation.

\section{Patients and methods}

Collection of peripheral blood leucocytes-From 1972 all patients with CGL diagnosed in our unit whose peripheral blood cells were con-

MRC Leukaemia Unit, Hammersmith Hospital, and Department of Haematology, Royal Postgraduate Medical School, London W12 OHS

I M GOLDMAN, BM, FRCP, honorary consultant physician

D CATOVSKY, MD, MRCPATH, honorary consultant physician

JILL HOWS, MB, MRCP, senior registrar

A S D SPIERS, MD, FACP, honorary consultant physician (present address : Division of Medical Oncology, Boston University Medical Centre, Boston MA 02118 USA)

D A G GALTON, MD, FRCP, honorary director, MRC Leukaemia Unit 
TABLE I-Management of first chronic phase in six patients with chronic granulocytic leukaemia who subsequently entered transformation (patients listed in sequence in which they came to autografting)

\begin{tabular}{|c|c|c|c|c|c|}
\hline \multirow[b]{2}{*}{$\begin{array}{l}\text { Case } \\
\text { No }\end{array}$} & \multirow{2}{*}{ Sex } & \multirow[b]{2}{*}{$\begin{array}{c}\text { Age* } \\
\text { (years) }\end{array}$} & \multirow{2}{*}{ Splenectomy } & \multicolumn{2}{|c|}{ Chronic phase } \\
\hline & & & & Treatment & $\begin{array}{l}\text { Duration } \\
\text { (months) }\end{array}$ \\
\hline $\begin{array}{l}1 \\
2 \\
3 \\
4\end{array}$ & $\begin{array}{l}\mathrm{M} \\
\mathbf{M} \\
\mathbf{F} \\
\mathbf{F}\end{array}$ & $\begin{array}{l}36 \\
20 \\
36 \\
56\end{array}$ & $\begin{array}{l}\text { Yes } \\
\text { No } \\
\text { Yes } \\
\text { Yes }\end{array}$ & $\begin{array}{l}\text { Busulphan (HD) } \\
\text { Busulphan (LD) } \\
\text { Busulphan (LD) } \\
\text { Busulphan, } \\
\text { cyclophosphamide, } \\
\text { melphalan, } \\
\text { hydroxyurea, } \\
\text { mercaptopurine, } \\
\text { demecolcine, } \\
\text { mitobronitol }\end{array}$ & $\begin{array}{l}14 \\
34 \\
34 \\
54\end{array}$ \\
\hline $\begin{array}{l}5 \\
6\end{array}$ & $\underset{\mathbf{M}}{\mathbf{M}}$ & $\begin{array}{l}35 \\
28\end{array}$ & $\begin{array}{l}\text { Yes } \\
\text { Yes }\end{array}$ & $\begin{array}{l}\text { Busulphan (HD) } \\
\text { Busulphan (LD), } \\
\text { mercaptopurine, } \\
\text { hydroxyurea }\end{array}$ & $\begin{array}{l}28 \\
53\end{array}$ \\
\hline
\end{tabular}

*At transformation.

HD = High dose.

chronic phase of their disease. ${ }^{12}$ Treatment during this phase varied considerably. Two patients received busulphan intermittently in single doses of 100 or $150 \mathrm{mg},{ }^{13}$ while three received it in conventional dosage. One patient received seven drugs administered as single agents in a predetermined sequence. ${ }^{1}$ The mean duration of the chronic phase in all six patients was 36.2 months (range 14-54 months).

Transformation was diagnosed when patients developed new clinical or haematological features of leukaemia that failed to respond to treatment with busulphan or hydroxyurea. Four patients had increasing numbers of blast cells or blasts plus promyelocytes in the blood and bone marrow. One patient (case 6) had fever and lytic lesions in bone associated with undifferentiated blasts and myeloblasts in the bone marrow. Another patient (case 4) had a transformation characterised by pancytopenia persisting for six months after the last treatment with cytotoxic drugs (fig 1). This patient's bone-marrow trephine repeatedly showed reduced cellularity with myelofibrosis and osteosclerosis; small foci of blast cells were also identified. Ultrastructural, cytochemical, and immunological characterisation of the blast cells was carried out in all cases except case $4 .{ }^{14}$ No patient had features of a lymphoblastic type of transformation (table II).

Once transformation was diagnosed the viability of stored buffycoat cells was tested by agar assay. All patients then received one, two, or three courses of the cytotoxic drug regimen (RATE) that we routinely use to manage acute myeloid leukaemia arising de novo. RATE consists of daunorubicin, cytarabine (cytosine arabinoside), and thioguanine in course 1 , followed after a 10-day rest by daunorubicin (or doxorubicin), cytarabine, and etoposide (epipodophyllotoxin) in course 2 . Course 3 , when necessary, comprises cytarabine,

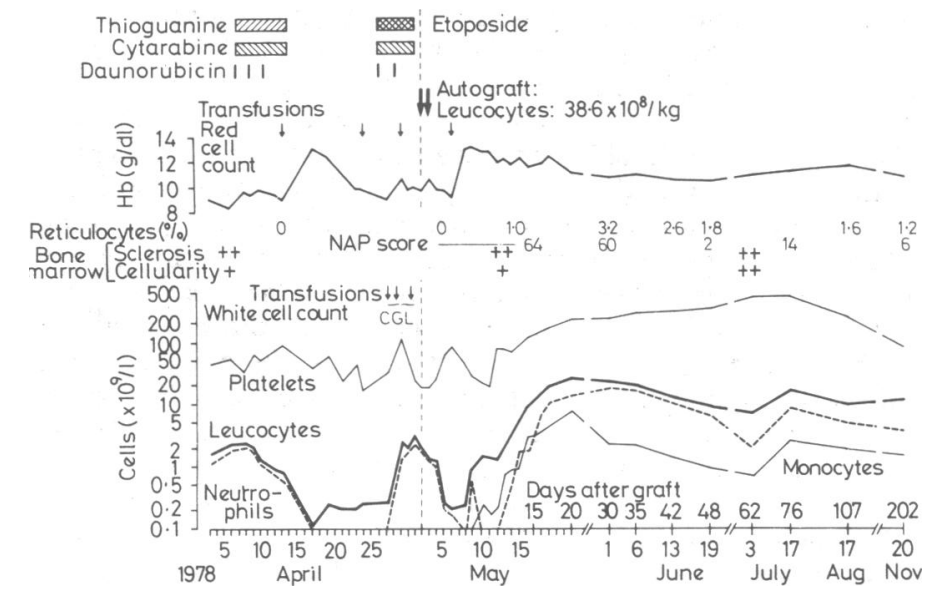

FIG 1-Haematological course at time of autograft in case 4. Peaks of leucocytes and neutrophils in blood at time of autograft were due to transfused allogeneic cells collected from donors with CGL. Note early appearance in blood of monocytes, which rose to peak value at day 20 after autograft. Bone-marrow fibrosis and cellularity of residual bone-marrow space expressed on scales of + to ++++ (normal cellularity represented as ++$)$. Normal neutrophil alkaline phosphatase (NAP) score is $30-90$ thioguanine, and etoposide. ${ }^{1516}$ One patient (case 2) also received radiotherapy to an enlarged spleen. The two patients treated last in the series (cases 5 and 6) received in addition cyclophosphamide in high dosage and total body irradiation. Cryopreserved cells were then reconstituted in two (or three) equal aliquots and transfused to the patients on two (or three) consecutive days, starting on the day after the end of the cytotoxic drugs or the total body irradiation, whichever came later. The mean number of leucocytes transfused was $23.6 \times$ $10^{8} / \mathrm{kg}$ (range 16.9 to 38.6 ) and the mean number of CFUc was $21 \cdot 0 \times 10^{5} / \mathrm{kg}$ (range $6 \cdot 1$ to $40 \cdot 5$ ) (table II).

TABLE II-Type of transformation and details of autografts in patients with CGL

\begin{tabular}{|c|c|c|c|c|c|c|}
\hline \multirow{2}{*}{$\begin{array}{l}\text { Case } \\
\text { No }\end{array}$} & \multirow{2}{*}{$\begin{array}{c}\text { Type of } \\
\text { transformation }\end{array}$} & \multirow{2}{*}{$\begin{array}{l}\text { Cytotoxic } \\
\text { drugs }\end{array}$} & \multirow{2}{*}{$\begin{array}{l}\text { Radio- } \\
\text { therapy }\end{array}$} & \multicolumn{3}{|c|}{ Buffy-coat cell autograft } \\
\hline & & & & $\begin{array}{l}\text { Duration } \\
\text { of storage } \\
\text { (months)( }\end{array}$ & $\begin{array}{l}\text { Leuco- } \\
\text { cytes } \\
\left.\times 10^{8} / \mathrm{kg}\right)\end{array}$ & $\underset{\left(\times 10^{s} / \mathrm{kg}\right)}{\text { CFUc }}$ \\
\hline$\frac{1}{2}$ & $\begin{array}{l}\text { Myeloblastic } \\
\text { Promyelocytic }\end{array}$ & \multirow{2}{*}{$\begin{array}{l}\text { RATE } \times 2 \\
\text { RATE } \times 2, \\
\text { Cyclo } \times 2 \\
\text { RATE } \times 3^{*}\end{array}$} & \multirow{2}{*}{$\begin{array}{c}\text { Nil } \\
\text { To spleen } \\
(800 \text { rads }) \\
\text { Nil }\end{array}$} & $\begin{array}{l}15 \\
36\end{array}$ & $\begin{array}{l}22 \cdot 8 \\
17 \cdot 2\end{array}$ & $\begin{array}{l}28 \cdot 5 \\
40.5\end{array}$ \\
\hline 3 & $\begin{array}{l}\text { Monoblastic and } \\
\text { megakaryoblastic }\end{array}$ & & & 33 & 16.9 & $6 \cdot 1$ \\
\hline 4 & $\begin{array}{l}\text { Myelosclerotic with } \\
\text { pancytopenia }\end{array}$ & RATE $\times 2$ & Nil & 58 & $38 \cdot 6$ & 24.9 \\
\hline 5 & Myeloblastic & \multirow{2}{*}{$\begin{array}{l}\text { RATE } \times 2 \\
\text { Cyclo (HD) } \\
\text { RATE } \times 1 \\
\text { Cyclo (HD) }\end{array}$} & \multirow{2}{*}{$\begin{array}{c}\text { TBI } \\
(600 \text { rads }) \\
\text { T BI } \\
(600 \text { rads })\end{array}$} & 29 & $25 \cdot 7$ & $8 \cdot 0$ \\
\hline 6 & $\begin{array}{l}\text { Myeloblastic with } \\
\text { lytic bone lesions }\end{array}$ & & & $50+$ & 20.5 & $18 \cdot 2$ \\
\hline
\end{tabular}

CFUc $=$ Colony forming units in agar culture

RATE $=$ Schedule of cytotoxic drugs (see text for details).

Cyclo = Cyclophosphamide.

HD $=$ High dose $(60 \mathrm{mg} / \mathrm{kg} \times 2)$.

* After transformation this patient was treated elsewhere with cytarabine and razoxane

(ICRF 159), to which her disease proved refractory, before she was referred back to the Hammersmith Hospital for consideration for autografting.

+ After original diagnosis this patient was treated briefly with busulphan, ending two months before cell storage.

TABLE III-Results of autografting in patients with $C G L$

\begin{tabular}{|c|c|c|c|c|c|c|c|}
\hline \multirow{3}{*}{$\begin{array}{l}\text { Case } \\
\text { No }\end{array}$} & \multicolumn{4}{|c|}{ Time (days) to recover to: } & \multirow{3}{*}{$\underset{\text { ment }}{\text { Engraft- }}$} & \multirow{3}{*}{$\begin{array}{c}\text { Time to } \\
\text { recurrent } \\
\text { trans- } \\
\text { formation } \\
\text { (weeks) }\end{array}$} & \multirow{3}{*}{$\begin{array}{l}\text { Survival } \\
\text { from } \\
\text { autograf } \\
\text { (weeks) }\end{array}$} \\
\hline & \multirow{2}{*}{$\frac{\begin{array}{c}\text { Reticulo- } \\
\text { cytes }\end{array}}{1 \%}$} & \multicolumn{2}{|c|}{$\begin{array}{l}\text { Polymorphonuclear } \\
\text { neutrophils }\end{array}$} & \multirow{2}{*}{$\begin{array}{l}\text { Platelets } \\
\overline{100 \times 10^{9} / 1}\end{array}$} & & & \\
\hline & & $1 \times 10^{\circ} / 1$ & $2 \times 10^{9} / 1$ & & & & \\
\hline $\begin{array}{l}1 \\
2 \\
3 \\
4 \\
5 \\
6\end{array}$ & $\begin{array}{r}99 \\
16 \\
\text { NA } \\
10 \\
10 \\
14\end{array}$ & $\begin{array}{r}8 \\
17 \\
5 \\
13 \\
12 \\
12\end{array}$ & $\begin{array}{c}12 \\
\text { (13 weeks) } \\
10 \\
15 \\
12 \\
16\end{array}$ & $\begin{array}{c}23 \\
\text { Never } \\
16 \\
15 \\
11 \\
12\end{array}$ & $\begin{array}{c}\text { Yes } \\
\text { Partial } \\
\text { Possible } \\
\text { Yes } \\
\text { Yes } \\
\text { Yes }\end{array}$ & $\begin{array}{l}74 \\
13 \\
1 \\
32 \\
26 \\
\text { NY }\end{array}$ & $\begin{array}{c}76^{*} \\
17 \\
6 \\
34^{*} \\
33^{*} \\
8^{*}\end{array}$ \\
\hline
\end{tabular}

*Patient alive on 31 December 1978.

$\mathrm{NA}=$ Not available.

NY $=$ Not yet occurred.

Though the intention was to render the marrow hypocellular before autografting, this was achieved with certainty only in cases 1,4 , and 5 . Two patients (cases 2 and 6 ) still had identifiable myeloid cells and one patient (case 3) still had occasional blast cells in the marrow. The autograft procedure was judged to be successful in four cases (table III). The mean duration of hospital stay after the autograft was 17 days for all six patients (range 13-20 days). The median time for all patients to recover a neutrophil count of $1 \times 10^{\circ} / 1\left(1000 / \mathrm{mm}^{3}\right)$ was 10 days after the autograft and for a recovery to $2 \times 10^{\circ} / 112$ days. The median time to reach a platelet count of $100 \times 10^{9} / 1$ was 16 days. In one patient (case 3) blast cells reappeared in the blood too soon to permit assessment of the possible "take" of the autograft. She died in blast crisis eight weeks after the autograft. In case 2 the recovery of granulocyte numbers in the blood suggested that the autograft was partially successful but the platelet count never exceeded $42 \times 10^{\circ} / 1$ and the patient continued to need blood transfusion. Haematological evidence of transformation recurred 13 weeks after the autograft. Splenectomy was undertaken but the patient died of a haemorrhage postoperatively.

In the four patients for whom the procedure appeared successful peripheral blood values and bone-marrow cellularity returned rapidly to a picture consistent with chronic-phase disease. One of these patients was still in the second chronic phase eight weeks after the autograft. In the other three patients transformation recurred at $\mathbf{7 4}$, 32 , and 26 weeks respectively. These patients were all well without 
any need for treatment during their second chronic phase. In one patient (case 5) the second transformation was predominantly promyelocytic. He was treated again with cytotoxic drugs followed by repeat autografting (leucocytes $12 \cdot 4 \times 10^{8} / \mathrm{kg}$, CFUc $52 \cdot 2 \times 10^{5} / \mathrm{kg}$ ) and was restored to a third chronic phase.

Blood CFUc at autografting-The numbers of peripheral blood CFUc were assayed on several occasions before, during, and after the autograft in five cases. Essentially parallel results were obtained in each case. No circulating CFUc were present in any patient immediately before the autograft. They could be shown in the blood immediately and for some hours after the autograft on day 0 but had declined to lower, though still measurable, numbers on day 1 before the second autograft. The numbers then rose after the second autograft to values comparable with those seen after the first autograft, fell to zero over the next three days, and then began to increase at about days 7 to 10 . Thereafter they rose steadily in parallel with the leucocyte count. A representative study is shown in fig 2 .

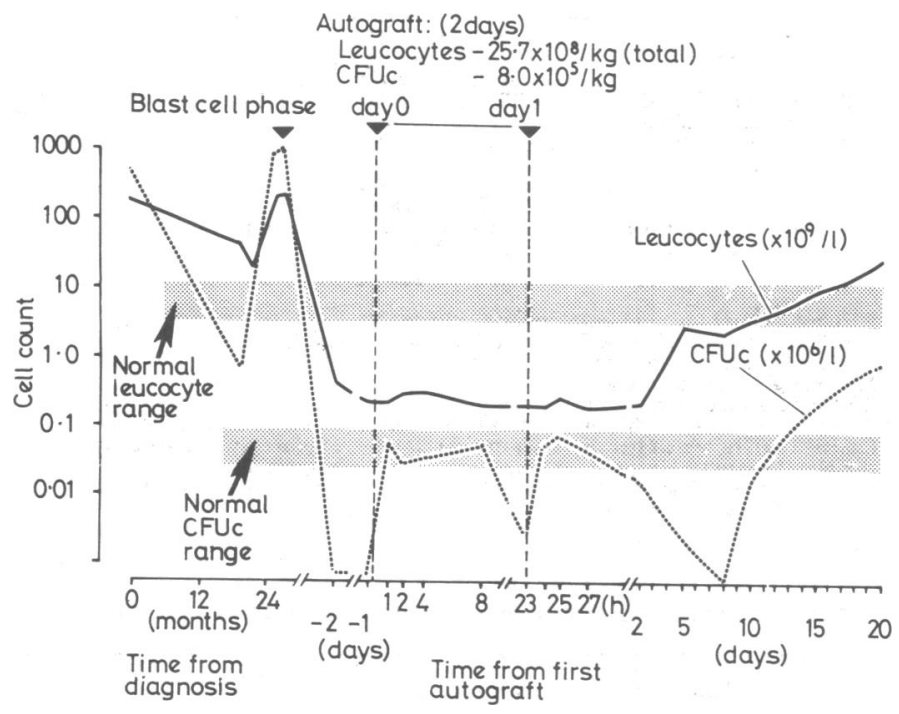

FIG 2-Numbers of blood leucocytes and CFUc immediately before, during, and after autograft in case 5 . CFUc numbers were high before treatment with cytotexic drugs.

Blood appearances after autografting-In the four patients for whom the procedure appeared to be successful the blood leucocyte count was rapidly restored to normal and then rose above the normal range. ${ }^{15} 16$ In case 1 the total leucocyte count appeared to fluctuate but did not exceed $100 \times 10^{\circ} / 1$ until 64 weeks after the autograft. In case 4 (fig 1) the leucocyte count reached a peak of $26.8 \times 10^{9} / 120$ days after the autograft, then declined into the normal range and subsequently rose again. In case 5 the leucocyte count rose more rapidly, reaching $43.8 \times 10^{\circ} / 118$ weeks after autografting. The earliest sign of engraftment was usually a rising number of reticulocytes in the peripheral blood. Subsequently nucleated red cells were present in large (case 4) or small numbers (cases 1,5 , and 6 ) for varying periods. Monocytes reappeared in the blood early after the autograft and reached peak values above the normal range at day 20 in case 4 (fig 1) and at day 18 in case 5. Their absolute numbers in the blood of the patient in case 1 were continuously raised during the second chronic phase. Neutrophil alkaline phosphatase values in patients in their second chronic phase were persistently extremely low. The blood lymphocyte count was greatly reduced in all patients at autograft. In the four in whom the procedure appeared successful the count was rapidly restored to normal or supranormal values, and some or many of the lymphocytes appeared reactive for some months. In one patient (case 5), who had received 600 rads of total body irradiation, the lymphocyte count rose steadily after the autograft to a peak of $11.1 \times 10^{\%} / 1$ at seven weeks then returned to normal values and rose again when transformation recurred. In this patient serum IgA concentrations were low during the first four months after the graft. IgG and $\operatorname{IgM}$ concentrations remained normal throughout the second chronic phase.

Bone-marrow appearances after autografting-In cases 1 and 5 the bone-marrow appearances in the second chronic phase were indistinguishable from those before transformation. In case 4 residual spaces in the bone marrow after autograft became hypercellular with cells compatible with chronic-phase disease. The density of reticulin appeared unchanged over six months. The marrow of one patient (case 6) contained almost exclusively necrotic-appearing cells at autograft but was rapidly restored to a chronic-phase picture.

Results of cytogenetic analyses-All six patients were $\mathrm{Ph}^{1}$-positive at diagnosis. Subsequently, complete cytogenetic data were not available because marrow preparations were often unsatisfactory owing to fibrosis or previous drug treatment. Further cytogenetic data were analysable in two of the four patients restored to a second chronic phase and in both showed persistence of the $\mathrm{Ph}^{1}$ chromosome.

\section{Discussion}

Pluripotential haemopoietic stem cells circulate in the blood of mice, ${ }^{17}$ dogs, ${ }^{18}$ and baboons. ${ }^{19}$ Pluripotential stem cells cannot yet be assayed in man but the observation that CFUc are present in the circulation, albeit in low numbers, suggests that these stem cells may also circulate. In patients with CGL blood CFUc are many thousands of times more numerous than in normal people, ${ }^{4}$ and pluripotential stem cells may reasonably be assumed to be increased too. Though it is generally agreed that human bone marrow is normally a better source of stem cells for autologous or allogeneic transplantation than peripheral blood, ${ }^{20}$ the unique exception may be when the donor has CGL.2

Marrow engraftment probably resulted from the transfusion of stored cells in at least four (cases $1,4,5$, and 6 ) of the six patients described here. Although in cases 1 and 4 the recovery of peripheral blood values and the repopulation of the marrow may possibly have resulted from the proliferation of residual endogenous chronic-phase stem cells, we believe that the rapidity of the recovery makes this interpretation unlikely. This possibility is virtually excluded in cases 5 and 6 because recovery of endogenous haemopoiesis could scarcely have occurred so rapidly after total body irradiation, if at all. We therefore conclude that enough stem cells are present in the blood of newly diagnosed patients with CGL to provide, after storage and reconstitution, an effective autograft when the bone marrow has been rendered hypoplastic with cytotoxic drugs or cytotoxic drugs plus total body irradiation. The observation that cells can be stored and will remain viable for five years, the longest storage time tested, implies that it may be possible to store them if necessary for a much longer period.

The failure of this type of management in two of the patients requires some comment. In case 2 we were struck by the relative resistance of the patient's spleen to both chemotherapy and radiotherapy. Possibly autografted stem cells settled in or were taken out of the circulation by the enlarged spleen and therefore failed to colonise the bone marrow. If this interpretation were correct it would suggest that the spleen ought to be removed before blood cell autografting for patients with CGL in transformation, preferably early in the chronic phase of the disease. One patient (case 3), on the other hand, had a highly aggressive form of blast cell transformation; her leucocyte count had continued to rise even while she was being treated initially elsewhere with cytarabine and razoxane, and small numbers of blast cells reappeared in her peripheral blood before courses 2 and 3 of cytotoxic drugs. Her disease may therefore have exemplified one end of a range at which transformation is so resistant that no effective antileukaemic treatment has yet been devised.

Of special interest is the observation that the marrow was engrafted rapidly in one patient (case 4), in whom the previous failure of haemopoiesis had been associated with increasing myelofibrosis and osteosclerosis. Ferrokinetic studies $\left({ }^{52} \mathrm{Fe}\right)$ before and after the autograft showed the resumption of erythropoiesis in the vertebral bodies and pelvis after the autograft.

We do not know whether the presumptive pluripotential stem cells in the blood of patients with CGL have full lymphoid as well as myeloid potential ${ }^{21}$ or whether they should more correctly be regarded as simply myeloid stem cells. We were therefore ? interested to see whether adequate recovery of lymphoid cells would take place in the patients who received total body irradiation as well as cytotoxic drugs. In the one patient (case 5) followed up for six months after irradiation this proved to be the 
case, and it appeared to be so in case 6 also. Buckner et al in Seattle recently reported the results of using cryopreserved autologous bone-marrow cells (supplemented in some cases by peripheral blood leucocytes) in the support of patients with CGL treated for transformation. ${ }^{22}$ They noted that reconstitution of lymphoid cells was defective in some of their patients. If, therefore, blood is a better source of pluripotential stem cells for autografting than bone marrow, ${ }^{2}$ this might be partly because relatively larger numbers of stem cells with lymphoid potential can be collected from the blood than from the marrow.

This approach to the management of CGL can in no sense be regarded as curative. Instead, our preliminary results suggest that it may prolong life in some cases for one or more years.

We thank Dr A W G Goolden, of Hammersmith Hospital, who supervised the administration of the radiotherapy. Valuable technical help was rendered by $M$ Cherchi, D S Park, K H Th'ng, M O'Brien, and S Pittman. We particularly thank members of the medical and nursing staff of the Hammersmith Hospital Anaemia Unit for their care in managing the patients. The agar culture work reported in this paper was supported in part by the Leukaemia Research Fund.

\section{References}

${ }^{1}$ Spiers, A S D, British fournal of Haematology, 1976, 32, 291.

${ }^{2}$ Goldman, J M, et al, British fournal of Haematology, 1978, 40, 185.
3 Graw, R G, jun, et al, Lancet, 1970, 2, 338

${ }^{4}$ Goldman, J M, et al, British fournal of Cancer, 1974, 30, 1.

5 Lowenthal, R M, et al, Leucocytes: Separation, Collection and Transfusion, ed J M Goldman and R M Lowenthal, pp 499-509. London, Academic Press, 1975.

${ }^{6}$ Hill, R S, et al, Cryobiology, 1973, 10, 1.

7 Lowenthal, R M, et al, British fournal of Haematology, 1976, 34, 105.

${ }^{8}$ Pike, B L, and Robinson, W A, Fournal of Cellular and Comparative Physiology, 1970, 76, 77.

9 Böyum, A, Scandinavian fournal of Clinical and Laboratory Investigation, 1968, 21, suppl No 97, p 31.

${ }^{10}$ Storring, R A, et al, Lancet, 1977, 2, 837

${ }^{11}$ Enno, A, et al, Lancet, 1978, 2, 395.

12 Spiers, A S D, et al, British Medical fournal, 1975, 1, 175.

13 Vicariot, M, et al, European fournal of Cancer. In press.

${ }^{14}$ Catovsky, D, et al, Bollettino dell'Istituto Sieroterapico Milunese, 1978, 57, 344.

15 Goldman, J M, Catovsky, D, and Galton, D A G, Lancet, 1978, 1, 437.

16 Goldman, J M, Seminars in Hematology, 1978, 15, 420.

17 Goldman, J M, and Th'ng, K H, Cryoconservation des Cellules Normales et Neoplasiques, ed R S Weiner, R K Oldham, and L Schwarzenberg, p 71. Paris, Institut National de la Sante et de la Recherche Médicale, 1973.

18 Nothdurft, W, et al, Scandinavian fournal of Haematology, 1977, 19, 470.

19 Storb, R, et al, Blood, 1977, 50, 537.

20 Storb, R, Prentice, R, and Thomas, E D, New England fournal of Medicine, 1977, 297, 58.

${ }^{21}$ Janossy, G, Roberts, M, and Greaves, M F, Lancet, 1976, 2, 1058

${ }^{22}$ Buckner, C D, et al, Experimental Hematology, 1978, 6, 96.

\title{
Biochemical testing for acute medical emergencies in four district general hospitals
}

\author{
B T WILLIAMS, R A DIXON
}

British Medical fournal, 1979, 1, 1313-1315

\section{Introduction}

The growth in the number of requests for clinical biochemistry tests has been disproportionately greater than the growth in the numbers of patients treated in hospitals. ${ }^{1}$ Automation of some tests and a change in the clinicians' approach to testing from being selective in their ordering to requesting complete biochemical profiles of their patients are generally accepted to have contributed to this increase. ${ }^{2}$ The work loads of radiodiagnostic and physiotherapy departments have not increased so appreciably. ${ }^{3}$ The necessity for so much biochemical investigation has been challenged, ${ }^{4}$ and the need to evaluate its effectiveness in improving clinical treatment and outcome suggested. ${ }^{5}$ Some idea is first needed, however, of the range of biochemical tests being carried out by laboratories in specific clinical cases, such as we report here for acute medical emergencies.

\section{Patients and methods}

We selected four district general hospitals in four large urban areas of the Trent region, each of which had a busy accident and emergency department and provided a wide range of clinical services. Hospitals A and B were teaching hospitals, hospital B having only recently been designated and being without clinical teaching at undergraduate level. In each hospital a consultant chemical pathologist headed the clinical biochemistry department. The degree to which testing was automated varied. In hospital A 10 types of test were performed by one machine during normal working hours; at other times a smaller, six-test machine was used. The machine at hospital B provided only two simultaneous estimations. Hospital $\mathrm{C}$ used a four-test and a

Department of Community Medicine, University of Sheffield Medical School, Sheffield S10 2RX

R A DIXON, BSC, PHD, senior lecturer in medical statistics 